\title{
Application of Ultrasonic Waves for the Improvement of Water Treatment
}

\author{
Akira Hiratsuka ${ }^{1}$, Dhundi Raj Pathak ${ }^{2,3}$ \\ ${ }^{1}$ Department of Civil Engineering, Osaka Sangyo University, Osaka, Japan \\ ${ }^{2}$ Engineering Study \& Research Centre, Kathmandu, Nepal \\ ${ }^{3}$ Solid Waste Management Technical Support Center, Ministry of Urban Development, Kathmandu, Nepal \\ Email: hiratuka@ce.osaka-sandai.ac.jp,draj28@yahoo.com
}

Received April 10, 2013; revised May 11, 2013; accepted June 4, 2013

Copyright (C) 2013 Akira Hiratsuka, Dhundi Raj Pathak. This is an open access article distributed under the Creative Commons Attribution License, which permits unrestricted use, distribution, and reproduction in any medium, provided the original work is properly cited.

\begin{abstract}
Application of ultrasonic waves is one of the novel techniques for the improvement of water treatment process. In this study, ultrasonic waves were irradiated to drinking water for water softening process and other contaminants removal. The experimental results showed that this technique improved the water treatment process efficiently. The study also revealed that the various parameters such as amplitude, frequency and irradiation time could affect the efficiency of ultrasound techniques for the improvement of water quality.
\end{abstract}

Keywords: Water Treatment; Ultrasonic Waves; Frequency; Irradiation Time; Water Quality

\section{Introduction}

Water is essential natural resources for the existence of life in the earth. However, sources of water are under crisis due to rapid urbanization and the increasing population, which demand more agricultural, industrial and domestic supplies. On the other hand, increasing anthropogenic activities in both developed and developing world have mounted heavy stresses on water quantity and quality [1].

An understanding that the water conservation at the source of drinking water rather than remediation and treatment is very important has been deepened. However, the water sources that have been already contaminated have to be treated to make safe drinking water. At present, the water purification treatment and its management have been fully carried out to respond citizens who require potable and tasty drinking water.

As a research theme of environmental engineering, numerous researchers are much interested in the development of new techniques to get a safe drinking water through purification of water resources [2]. But, development of a novel as well as sustainable and cost effective techniques for the removal of pollutants from drinking water is the challenging issue for environmental professionals.

The most widely applied water treatment processes, a combination of some or all of coagulation, flocculation, sedimentation and filtration to reduce or eliminate turbidity and improve water quality [3]. Moreover, ion exchange, carbon adsorption, membrane processes and disinfection are generally used to remove contaminants in traditional water purification system. Above processes have some purification limitation and application problems such as high cost, ineffective for removal some pollutant, operation problems and generate toxic secondary pollutants [4]. Such a limitation can be eliminated by the application of innovative techniques such as semiconductor catalysts, forward osmoses, advances oxidation process and magnetic purification [5]. There are several applications of irradiation of ultrasonic waves into fluids $[6,7]$. It is reported that physical phenomena (effect) such as cleaning, emulsification, cavitation, promotion of reaction etc. happen when small amplitude and high-frequency waves (ultrasonic waves) are irradiated in the water with impurities. Ultrasound is cyclic sound pressure with a frequency greater than the upper limit of human hearing, which is approximately 20 kilohertz [8]. Among the numerous applications of ultrasound, the approach is used in the field of water treatment. The application of ultrasonic waves improves water treatment process efficiently.

Ultrasound waves were irradiated to water with impurities mainly to examine 1) a condition of ultrasonic 
waves to accelerate the reaction better and 2) a condition of the softenization of hard water and removal of other impurities from drinking water. Then the removal rate of impurities from drinking water has been shown when changing the amplitude and frequency of ultrasonic waves. Moreover, by changing the ultrasonic wave condition, fundamental investigation of the content of various water quality parameters such as calcium $(\mathrm{Ca})$, sodium $(\mathrm{Na})$, potassium $(\mathrm{K})$, silicic acid $\left(\mathrm{SiO}_{2}\right)$, sulphate ion $\left(\mathrm{SO}_{4}^{2-}\right)$ and magnesium $(\mathrm{Mg})$ etc. is conducted.

\section{Experimental Procedures}

\subsection{Ultrasonic System}

An ultrasonic cleaner used in this experiment is shown in Figure 1. A specification of the ultrasonic cleaner is as follows: Model: SC-320F, Output: $300 \mathrm{~W}$, Power source: AC100 V, 50/60 Hz 6 A, Oscillated frequency: $28 \mathrm{KHz} \pm$ $10 \%$, Date of manufacture: May 2010, Equipment number: 3 Y0101, Maker: STM Co. Ltd., Japan.

\subsection{Experimental Condition}

In this study, the standpoint is to understand how the hardness and other contaminants are decreased in each water sample by irradiating ultrasonic waves. An irradiation experiment was carried out using an ultrasonic cleaner as shown in Figure 1 at a frequency of $28 \mathrm{KHz}$ as mentioned above in this experiment. Here we confirmed that the influence on position of the samples is not relating to the result. An experimental condition is as follows:

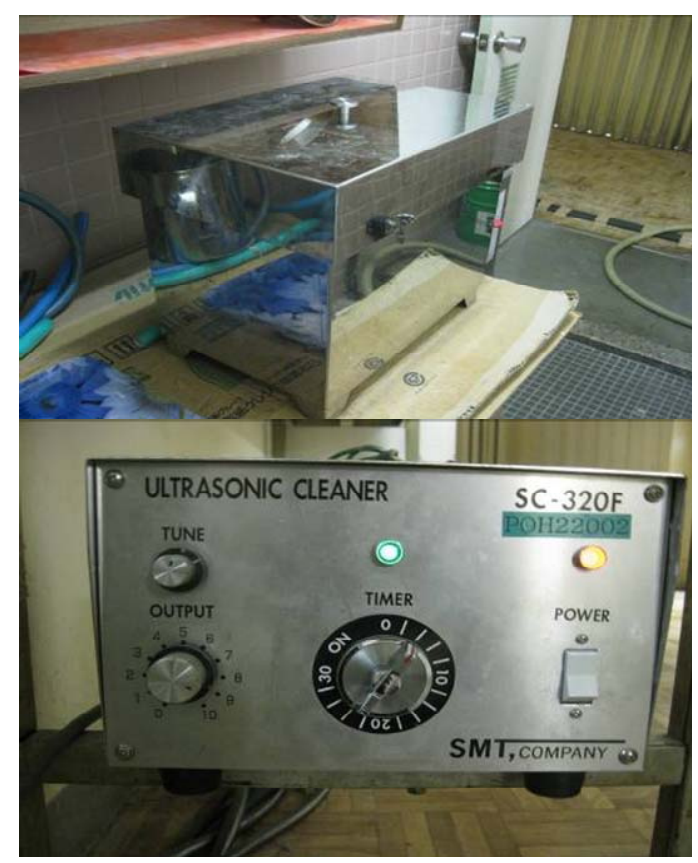

Figure 1. Photograph showing ultrasonic system.
Irradiation time: $30 \mathrm{~min} ., 20 \mathrm{~min}$. and $10 \mathrm{~min}$. (3 phases).

Test sample of drinking water focusing hardness: 6 kinds (Table 1).

It is easy for us to get all drinking waters except for drinking water $\mathbf{2}$ because of a purchasing system in which only special contracted buyer can get. Items of water qualities centering "hardness" such as $\mathrm{Ca}, \mathrm{Mg}, \mathrm{pH}$ and those regarding drinking water indexes for healthy $(\mathrm{Ca}$ and $\mathrm{Na}$ ) and/or tasty $\left(\mathrm{Ca}, \mathrm{K}, \mathrm{SiO}_{2}, \mathrm{Mg}\right.$ and $\left.\mathrm{SO}_{4}^{2-}\right)$ are picked up in Table 2. A theoretical calculation Equation (1) as mentioned below is well-known as an expression of hardness.

$$
\begin{aligned}
& \text { Hardness }[\mathrm{mg} / \mathrm{L}] \cong(\text { Amount of } \mathrm{Ca}[\mathrm{mg} / \mathrm{L}] \times 2.5) \\
& +(\text { Amount of } \mathrm{Mg}[\mathrm{mg} / \mathrm{L}] \times 4.1)
\end{aligned}
$$

A calculation result of "hardness" using $\mathrm{Ca}$ and $\mathrm{Mg}$ is almost as same as the value expressed in the label of each drinking water, respectively. However, regarding drinking water 2, although $\mathrm{Ca}$ and $\mathrm{Mg}$ were expressed in the label, "hardness" was not expressed. Therefore, Hardness has been calculated using the Equation (1). As a result, we got the value of $59(\mathrm{mg} / \mathrm{L})$ as a theoretical one, which is quite higher than that of actual value $15(\mathrm{mg} / \mathrm{L})$. In addition, this value $59(\mathrm{mg} / \mathrm{L})$ is quite higher in comparison with that of other 5 drinking waters. Then we tried to measure the amount of $\mathrm{Ca}$ and $\mathrm{Mg}$ regarding the drinking water 2 once more. As a result, we confirmed a difference between the value of the label and actual measured value. In addition, water qualities parameters such as $\mathrm{Na}, \mathrm{K}, \mathrm{SO}_{4}^{2-}$ and $\mathrm{BOD}$ at irradiation time 30 min are shown in Table 2.

Table 1. Description of drinking water samples.

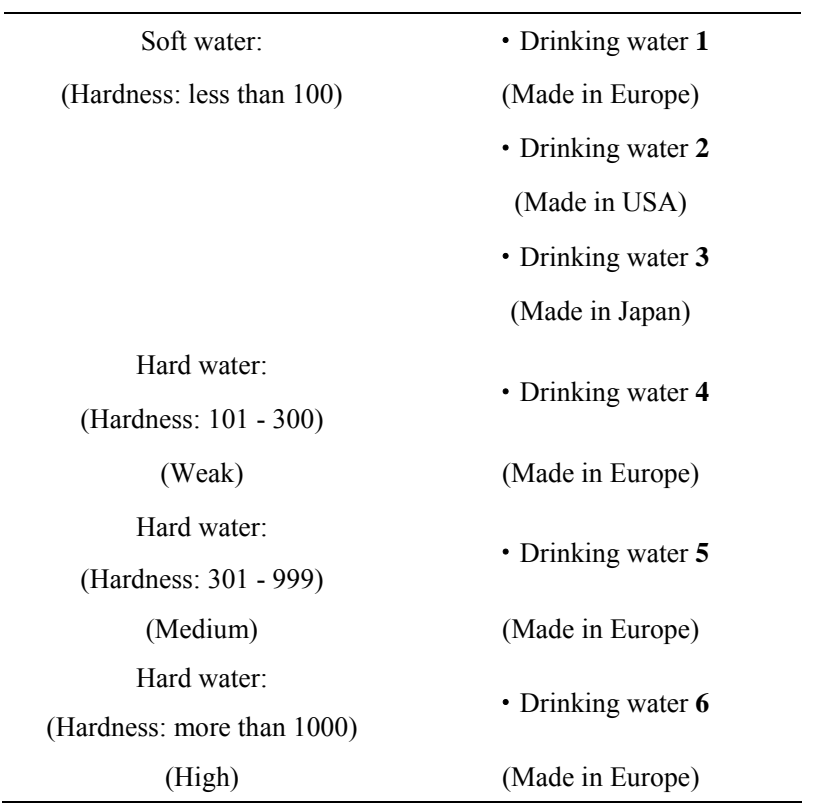


Table 2. Experimental results (Irradiation time: 30 min., water temp.: $22.7^{\circ} \mathrm{C}$ (start) - $27.9^{\circ} \mathrm{C}$ (end)).

\begin{tabular}{|c|c|c|c|c|c|c|}
\hline $\begin{array}{l}\text { Test sample } \Rightarrow \\
\text { Water quality } \Downarrow\end{array}$ & $\begin{array}{c}\text { Drinking } \\
\text { water } 1\end{array}$ & $\begin{array}{l}\text { Drinking } \\
\text { water } 2\end{array}$ & $\begin{array}{c}\text { Drinking } \\
\text { water } 3\end{array}$ & $\begin{array}{l}\text { Drinking } \\
\text { water } 4\end{array}$ & $\begin{array}{l}\text { Drinking } \\
\text { water } 5\end{array}$ & $\begin{array}{l}\text { Drinking } \\
\text { water } 6\end{array}$ \\
\hline Hardness (mg/L) & $60 \rightarrow 35$ & $15 \rightarrow 5$ & $32 \rightarrow 15$ & $304 \rightarrow 100$ & $315 \rightarrow 150$ & $1468 \rightarrow 150$ \\
\hline $\operatorname{Rr}(\%)$ & 41.7 & 66.7 & 53 & 67.1 & 52.4 & 89.8 \\
\hline pH & $7.0 \rightarrow 7.7$ & $6.7 \rightarrow 8.3$ & $8.3 \rightarrow 8.5$ & $7.2 \rightarrow 7.8$ & $7.8 \rightarrow 8.2$ & $7.4 \rightarrow 7.8$ \\
\hline COD (mg/L) & $7 \rightarrow 7$ & $8 \rightarrow 12$ & $7 \rightarrow 11$ & $7 \rightarrow 11.5$ & $3 \rightarrow 11$ & $5 \rightarrow 8$ \\
\hline $\operatorname{Rr}(\%)$ & 0 & -50 & -57.1 & -64.3 & -266.7 & -60 \\
\hline $\mathrm{Mg}^{2+}(\mathrm{mg} / \mathrm{L})$ & $8 \rightarrow 8$ & $12 \rightarrow 1.5$ & $1.9 \rightarrow 0.5$ & $26 \rightarrow 15$ & $20 \rightarrow 15$ & $74.5 \rightarrow \geqq 20$ \\
\hline $\operatorname{Rr}(\%)$ & 0 & 87.5 & 73.7 & 42.3 & 25 & 73.2 \\
\hline $\mathrm{Ca}^{2+}(\mathrm{mg} / \mathrm{L})$ & $11.5 \rightarrow 11.5$ & $3.9 \rightarrow 1$ & $9.6 \rightarrow 7$ & $80 \rightarrow 30$ & $94 \rightarrow 30$ & $468 \rightarrow 45$ \\
\hline $\operatorname{Rr}(\%)$ & 0 & 74.4 & 27.1 & 62.5 & 68.1 & 90.4 \\
\hline $\mathrm{SiO}_{2}(\mathrm{mg} / \mathrm{L})$ & $35 \rightarrow 35$ & $3 \rightarrow 0.8$ & $90 \rightarrow 90$ & $15 \rightarrow 15$ & $10 \rightarrow 10$ & $8 \rightarrow 8$ \\
\hline $\operatorname{Rr}(\%)$ & 0 & 73.3 & 0 & 0 & 0 & 0 \\
\hline $\mathrm{Na}^{+}(\mathrm{mg} / \mathrm{L})$ & $11.6 \rightarrow 0.8$ & $9.6 \rightarrow 4.7$ & $2.2 \rightarrow 1.3$ & $7 \rightarrow 0.7$ & $7.7 \rightarrow 0.4$ & $9.4 \rightarrow 1.1$ \\
\hline $\operatorname{Rr}(\%)$ & 93.1 & 51 & 40.9 & 90 & 94.8 & 88.3 \\
\hline $\mathrm{K}^{+}(\mathrm{mg} / \mathrm{L})$ & $6.2 \rightarrow 1.8$ & $3.6 \rightarrow 1.6$ & $8.4 \rightarrow 2.4$ & $0.3 \rightarrow 0.3$ & $5 \rightarrow 1.5$ & $2.8 \rightarrow 1.3$ \\
\hline $\operatorname{Rr}(\%)$ & 71 & 55.6 & 71.4 & 0 & 70 & 53.6 \\
\hline TSO4 (mg/L) & $7.5 \rightarrow 24$ & $7.0 \rightarrow 19$ & $3.0 \rightarrow 25$ & $12 \rightarrow 33$ & $100 \rightarrow 110$ & $1100 \rightarrow 1100$ \\
\hline $\operatorname{Rr}(\%)$ & -220 & -171 & -733 & -175 & -10 & 0 \\
\hline BOD (mg/L) & $3 \rightarrow 3$ & $4 \rightarrow 4$ & $3 \rightarrow 3$ & $3 \rightarrow 4$ & $2 \rightarrow 6$ & $2 \rightarrow<2$ \\
\hline $\operatorname{Rr}(\%)$ & 0 & 0 & 0 & -33.3 & -20 & trace \\
\hline
\end{tabular}

\subsection{Analytical Method of Water Quality}

The analysis of the water quality was conducted in the laboratory. Simplified water quality analysis kit made by Kyoritsu chemical-check lab., corp., Japan was used for examining Hardness, $\mathrm{pH}, \mathrm{COD}, \mathrm{Mg}, \mathrm{Ca}, \mathrm{SiO}_{2}$. and ICP emission spectrometry for $\mathrm{Na}$ and $\mathrm{K}$, and ion chromatography for $\mathrm{SO}_{4}^{2-}$, and diaphragm electrode method for BOD, respectively.

\section{Results and Discussions}

All measured results are shown in Tables 2-4. The $\mathrm{pH}$ value increases after irradiating in all cases. This estimates that sulfate $\left(\mathrm{SO}_{4}^{2-}\right)$ decreases and combines with a chemical compound (neutralization). That is, it is suggestive of the occurrence of the following reactions.

$$
\begin{aligned}
& \mathrm{Mg}^{2+}+\mathrm{SO}_{4}^{2-} \rightarrow \mathrm{MgSO}_{4} \\
& \mathrm{Ca}^{2+}+\mathrm{SO}_{4}^{2-} \rightarrow \mathrm{CaSO}_{4} \\
& 2 \mathrm{Na}^{+}+\mathrm{SO}_{4}^{2-} \rightarrow \mathrm{Na}_{2} \mathrm{SO}_{4} \\
& 2 \mathrm{~K}^{+}+\mathrm{SO}_{4}^{2-} \rightarrow \mathrm{K}_{2} \mathrm{SO}_{4}
\end{aligned}
$$

Therefore these reactions seem to be roughly appropriate $\left(\mathrm{K}^{+} \fallingdotseq \mathrm{Na}^{+}, \mathrm{Ca}^{+}, \mathrm{Mg}^{+}\right)$in considering the decreasing trend of the concentration. In addition, we see that $\mathrm{SO}_{4}^{2-}$ does not increase in spite of the decrease of
$\mathrm{Ca}$ in drinking water 5 and 6 . It is probably due to a problem of the analytical precision exists. Furthermore, the question has been raised on why $\mathrm{SO}_{4}^{2-}$ is originally high or where this ion comes from in drinking water 5 and 6. Figure 2 shows a comparison of changing hardness between irradiation time $0 \mathrm{~min}$. and $30 \mathrm{~min}$ (immediately after experiment). It is understandable that hardness in each sample is decreasing. First of all, drinking water $\mathbf{6}$ is about one tenth compared with at $0 \mathrm{~min}$. and next, about one second for drinking waters 1, 3 and 5, and then, about one third for drinking waters $\mathbf{2}$ and $\mathbf{4}$, respectively. In the experiment, a decreasing of concentration of $\mathrm{Ca}$ and $\mathrm{Mg}$ is observed in the water. It is thought that this is due to an effect of ultrasonic waves. It is estimated that this is due to the liberation of the solid and solidification of the same substances $(\mathrm{Ca}, \mathrm{Mg})$ because suspended solids are observed in the water (concentration drop in water). And a slight increase of the temperature by activation of molecular motion due to the irradiation of ultrasonic waves is also observed. It is known from the standpoint of property of water that a saturated concentration increases associated with the increase of water temperature. However, the reverse change is brought in this experiment (decrease of saturated concentration). In addition, it is thought that a possibility of undergoing any oxidation-reduction reaction 
Table 3. Experimental results (Irradiation time: 20 min., water temp.: $29.0^{\circ} \mathrm{C}$ (start) - $31.7^{\circ} \mathrm{C}$ (end)).

\begin{tabular}{|c|c|c|c|c|c|c|}
\hline $\begin{array}{l}\text { Test sample } \Rightarrow \\
\text { Water quality } \Downarrow\end{array}$ & $\begin{array}{c}\text { Drinking } \\
\text { water } 1\end{array}$ & $\begin{array}{c}\text { Drinking } \\
\text { water } 2\end{array}$ & $\begin{array}{c}\text { Drinking } \\
\text { water } 3\end{array}$ & $\begin{array}{c}\text { Drinking } \\
\text { water } 4\end{array}$ & $\begin{array}{c}\text { Drinking } \\
\text { water } 5\end{array}$ & $\begin{array}{c}\text { Drinking } \\
\text { water } 6\end{array}$ \\
\hline Hardness (mg/L) & $60 \rightarrow 20$ & $15 \rightarrow 5$ & $32 \rightarrow 15$ & $304 \rightarrow 50$ & $315 \rightarrow 75$ & $1468 \rightarrow 75$ \\
\hline $\operatorname{Rr}(\%)$ & 66.7 & 66.7 & 53.1 & 83.6 & 76.2 & 94.9 \\
\hline pH & $7.0 \rightarrow 7.2$ & $6.7 \rightarrow 6.2$ & $8.3 \rightarrow 7.5$ & $7.2 \rightarrow 6.8$ & $7.8 \rightarrow 7.2$ & $7.4 \rightarrow 7.2$ \\
\hline $\operatorname{COD}(\mathrm{mg} / \mathrm{L})$ & $7 \rightarrow 2.5$ & $8 \rightarrow 5$ & $7 \rightarrow 2.5$ & $7 \rightarrow 2.5$ & $3 \rightarrow 3$ & $5 \rightarrow 2.5$ \\
\hline $\operatorname{Rr}(\%)$ & 64.3 & 37.5 & 64.3 & 64.3 & 0 & 50 \\
\hline $\mathrm{Mg}^{2+}(\mathrm{mg} / \mathrm{L})$ & $8 \rightarrow 3.5$ & $12 \rightarrow 0.5$ & $1.9 \rightarrow 0.2$ & $26 \rightarrow 8$ & $20 \rightarrow 8$ & $74.5 \rightarrow 15$ \\
\hline $\operatorname{Rr}(\%)$ & 56.3 & 95.8 & 89.5 & 69.2 & 60 & 79.9 \\
\hline $\mathrm{Ca}^{2+}(\mathrm{mg} / \mathrm{L})$ & $11.5 \rightarrow 8$ & $3.9 \rightarrow 0.5$ & $9.6 \rightarrow 7$ & $80 \rightarrow 15$ & $94 \rightarrow 15$ & $468 \rightarrow 15$ \\
\hline $\operatorname{Rr}(\%)$ & 30.4 & 87.2 & 27.1 & 81.3 & 84 & 96.8 \\
\hline $\mathrm{SiO}_{2}(\mathrm{mg} / \mathrm{L})$ & $35 \rightarrow 35$ & $3 \rightarrow 0.8$ & $90 \rightarrow 90$ & $15 \rightarrow 15$ & $10 \rightarrow 10$ & $8 \rightarrow 8$ \\
\hline $\operatorname{Rr}(\%)$ & 0 & 73.3 & 0 & 0 & 0 & 0 \\
\hline BOD (mg/L) & $3 \rightarrow 3$ & $4 \rightarrow 4$ & $3 \rightarrow 3$ & $3 \rightarrow 2$ & $2 \rightarrow 3$ & $2 \rightarrow 4$ \\
\hline $\operatorname{Rr}(\%)$ & 0 & 0 & 0 & 50 & -50 & -100 \\
\hline
\end{tabular}

Rr: Removal rate.

Table 4. Experimental results (Irradiation time: $10 \mathrm{~min}$., water temp.: $30.6^{\circ} \mathrm{C}$ (start) - $32.5^{\circ} \mathrm{C}$ (end)).

\begin{tabular}{|c|c|c|c|c|c|c|}
\hline $\begin{array}{l}\text { Test sample } \Rightarrow \\
\text { Water quality }\end{array}$ & $\begin{array}{c}\text { Drinking } \\
\text { water } 1\end{array}$ & $\begin{array}{c}\text { Drinking } \\
\text { water } 2\end{array}$ & $\begin{array}{c}\text { Drinking } \\
\text { water } 3\end{array}$ & $\begin{array}{c}\text { Drinking } \\
\text { water } 4\end{array}$ & $\begin{array}{l}\text { Drinking } \\
\text { water } 5\end{array}$ & $\begin{array}{c}\text { Drinking } \\
\text { water } 6\end{array}$ \\
\hline Hardness (mg/L) & $60 \rightarrow 20$ & $15 \rightarrow 5$ & $32 \rightarrow 15$ & $304 \rightarrow 35$ & $315 \rightarrow 75$ & $1468 \rightarrow 50$ \\
\hline $\operatorname{Rr}(\%)$ & 66.7 & 66.7 & 53.1 & 88.5 & 76.2 & 96.6 \\
\hline $\mathbf{p H}$ & $7.0 \rightarrow 7.2$ & $6.7 \rightarrow 6.2$ & $8.3 \rightarrow 7.6$ & $7.2 \rightarrow 7.2$ & $7.8 \rightarrow 7.2$ & $7.4 \rightarrow 6.8$ \\
\hline COD (mg/L) & $7 \rightarrow 1.5$ & $8 \rightarrow 2$ & $7 \rightarrow 2.5$ & $7 \rightarrow 2$ & $3 \rightarrow 2$ & $5 \rightarrow 2$ \\
\hline $\operatorname{Rr}(\%)$ & 78.6 & 75 & 64.3 & 71.4 & 33.3 & 60 \\
\hline $\mathrm{Mg}^{2+}(\mathrm{mg} / \mathrm{L})$ & $8 \rightarrow 3.5$ & $12 \rightarrow 0.3$ & $1.9 \rightarrow 0.1$ & $26 \rightarrow 88$ & $20 \rightarrow 8$ & $74.5 \rightarrow 8$ \\
\hline $\operatorname{Rr}(\%)$ & 56.3 & 97.5 & 94.7 & 69.2 & 60 & 89.3 \\
\hline $\mathrm{Ca}^{2+}(\mathrm{mg} / \mathrm{L})$ & $11.5 \rightarrow 7$ & $3.9 \rightarrow 0.2$ & $9.6 \rightarrow 7$ & $80 \rightarrow 15$ & $94 \rightarrow 15$ & $468 \rightarrow 1414$ \\
\hline $\operatorname{Rr}(\%)$ & 39.1 & 94.9 & 27.1 & 43.8 & 84 & 97 \\
\hline $\mathrm{SiO}_{2}(\mathrm{mg} / \mathrm{L})$ & $35 \rightarrow 35$ & $3 \rightarrow 0.8$ & $90 \rightarrow 90$ & $15 \rightarrow 15$ & $10 \rightarrow 10$ & $8 \rightarrow 8$ \\
\hline $\operatorname{Rr}(\%)$ & 0 & 73.3 & 0 & 0 & 0 & 0 \\
\hline BOD (mg/L) & $3 \rightarrow 3$ & $4 \rightarrow 4$ & $3 \rightarrow 3$ & $3 \rightarrow 6$ & $2 \rightarrow 5$ & $2 \rightarrow 4$ \\
\hline $\operatorname{Rr}(\%)$ & 0 & 0 & 0 & -100 & -150 & -100 \\
\hline
\end{tabular}

Rr: Removal rate.

as the change for $\mathrm{pH}$ and COD can be seen.

Figure 3 shows a comparison of hardness among irradiation time $30 \mathrm{~min}$., $20 \mathrm{~min}$. and $10 \mathrm{~min}$. The experimental results confirmed an increase of about $5^{\circ} \mathrm{C}$ with respect to the irradiation time $30 \mathrm{~min}$.

Then we carried out an examination decreasing irradiation time (20 min. \& $10 \mathrm{~min}$.) and recorded the corresponding temperature. In irradiation time of $20 \mathrm{~min}$. and $10 \mathrm{~min}$., the increase of the temperature came to about $2^{\circ} \mathrm{C}$. Under this temperature, it was found lower value of many water quality parameters including hardness. It is observed in the experiment that the extent of suspended solid in the water after irradiating the time of $20 \mathrm{~min}$. and $10 \mathrm{~min}$. is almost equal to the case for $30 \mathrm{~min}$. Therefore, it seems that the irradiation by ultrasonic waves is brought into the result in which many water quality parameters are shown lower tendency. However, at present it is very difficult to compare with the effect among irradiation times ( $30 \mathrm{~min} ., 20 \mathrm{~min}$. and $10 \mathrm{~min}$.) quantitatively (for example, short irradiation time is more effec- 


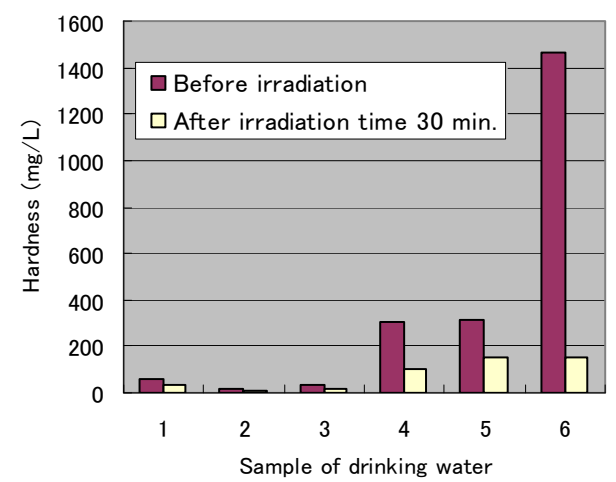

Figure 2. Change of hardness after irradiation time (30 min.).

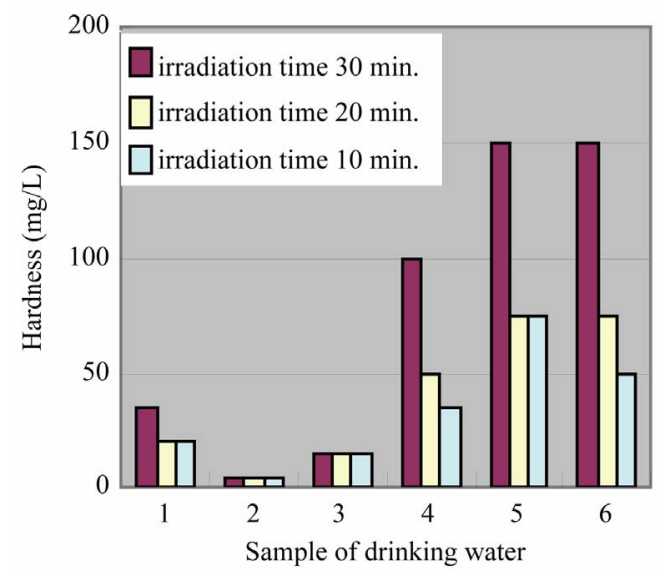

Figure 3. Comparison of hardness among irradiation time 30,20 and $10 \mathrm{~min}$.

tive than long one regarding the change of "hardness."), which warranting further examination on this.

Figures 4-8 show a change of water qualities such as $\mathrm{Ca}, \mathrm{K}, \mathrm{SiO}_{2}, \mathrm{Mg}$ and $\mathrm{SO}_{4}^{2-}$ of drinking water at irradiation time $30 \mathrm{~min}$. These items of water qualities are items on tasty water index (O Index) [9]. This O Index is shown in Equation (2), it is recognized that the value of more than 2 in $\mathrm{O}$ Index is tasty drinking water.

$$
\mathrm{Ca}+\mathrm{K}+\mathrm{SiO}_{2} / \mathrm{Mg}+\mathrm{SO}_{4}^{2-}
$$

In all drinking waters, there is not a large change in a denominator $\left(\mathrm{Mg}+\mathrm{SO}_{4}^{2-}\right)$, but large change in a numerator $\left(\mathrm{Ca}+\mathrm{K}\right.$ [except for $\left.\left.\mathrm{SiO}_{2}\right]\right)$. Therefore, there seems to be a possibility that an irradiation by ultrasonic waves to drinking water increases the O-index which means that the taste of water is improved. Figure 9 shows a change of water quality of $\mathrm{Na}$ of drinking water at irradiation time $30 \mathrm{~min}$. This water quality parameter together with $\mathrm{Ca}$ are related to taste of drinking water which is called $\mathrm{K}$ index and given in Equation (3). It is recognized that the value of $\mathrm{K}$ index more than 5.2 is wholesome drinking water.

$$
\mathrm{Ca}-0.87 \mathrm{Na}
$$

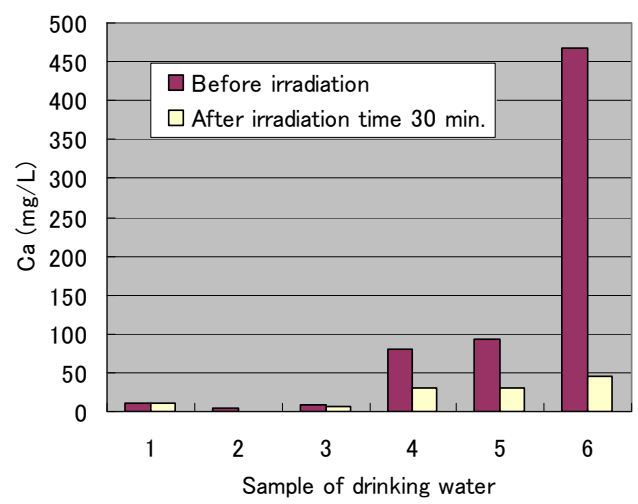

Figure 4. Change of $\mathrm{Ca}$ at irradiation time $30 \mathrm{~min}$.

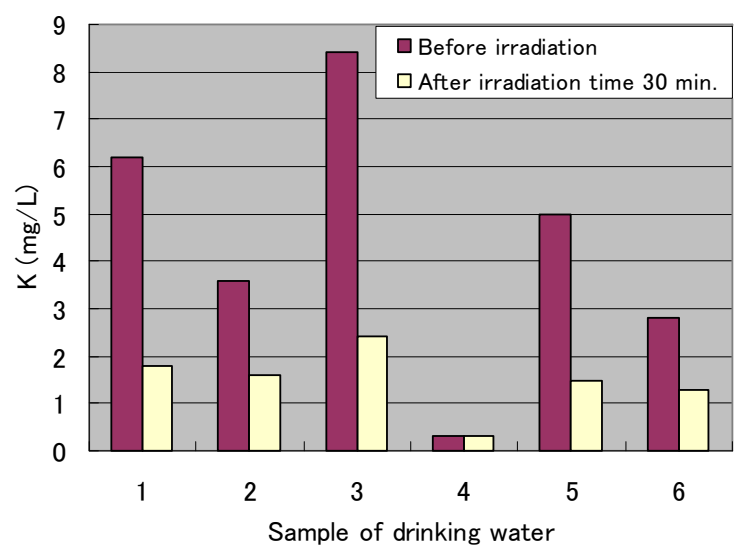

Figure 5. Change of $\mathrm{K}$ at irradiation time $30 \mathrm{~min}$.

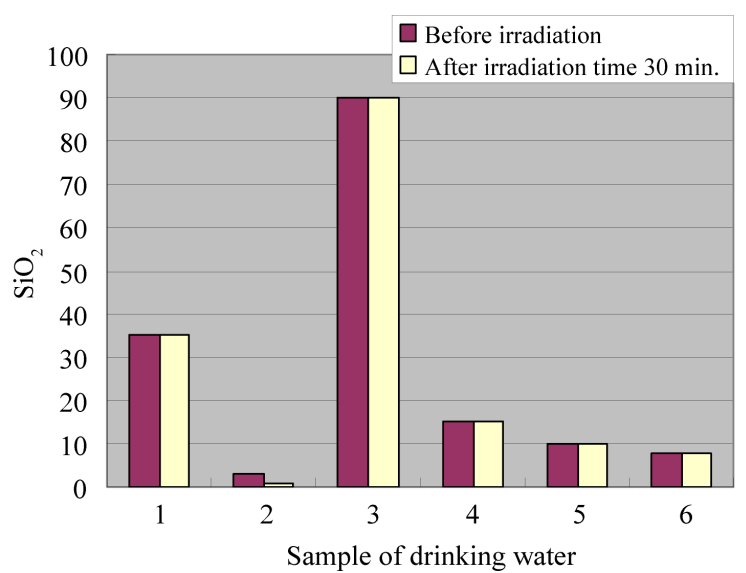

Figure 6. Change of $\mathrm{SiO}_{2}$ at irradiation time $30 \mathrm{~min}$.

It does not exist large difference in the drinking waters 1, 2 and 3 for $\mathrm{Ca}$, but exists large one in drinking waters 4,5 and 6 , respectively. In addition, there is a decreasing tendency for $\mathrm{Na}$ in all drinking waters. Especially, it is understandable that the drinking waters 2 and 3 have a large change. Therefore, there seems to be a possibility that an irradiation by ultrasonic waves improve the quality and taste of water significantly.

Figures 10-12 show a removal rate of Hardness, BOD 


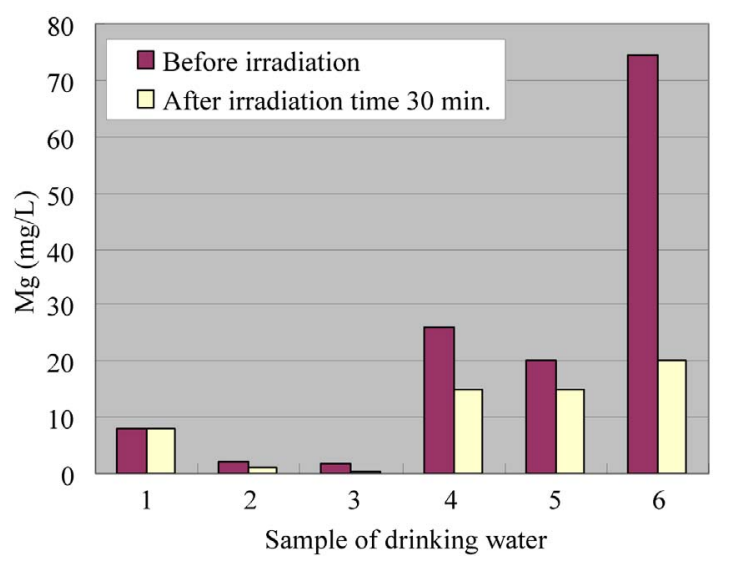

Figure 7. Change of $\mathrm{Mg}$ at irradiation time $30 \mathrm{~min}$.

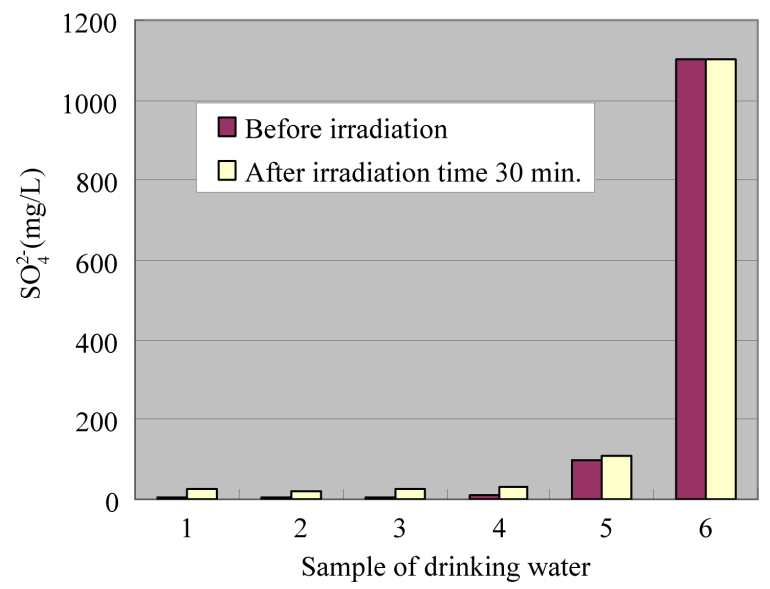

Figure 8. Change of $\mathrm{SO}_{4}^{2-}$ at irradiation time $30 \mathrm{~min}$.

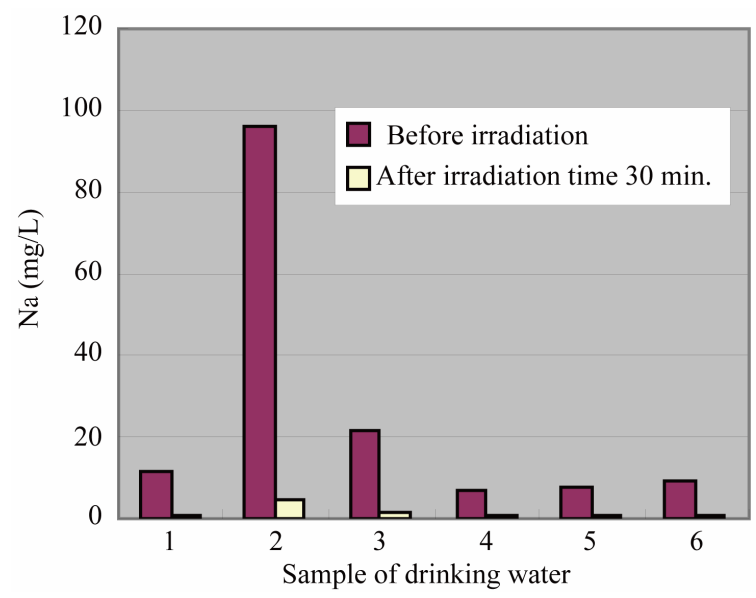

Figure 9. Change of $\mathrm{Na}$ at irradiation time $30 \mathrm{~min}$.

and COD in different irradiation time (10 min., $20 \mathrm{~min}$. and $30 \mathrm{~min}$.), respectively. As can be seen from Figures 10-12, the removal rate of the hardness component showed about $42 \%-90 \%$ in irradiation of $30 \mathrm{~min}$., about $53 \%$ - 95\%, $20 \mathrm{~min}$. and about 53\% - 97\%, 10 min., respectively. All the values showed the positive ones (in

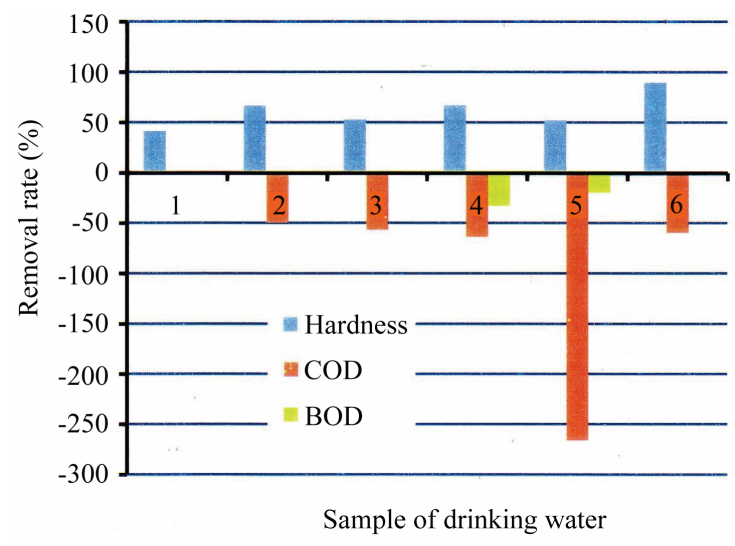

Figure 10. Removal rate of hardness, COD and BOD due to irradiation time (30 min.).

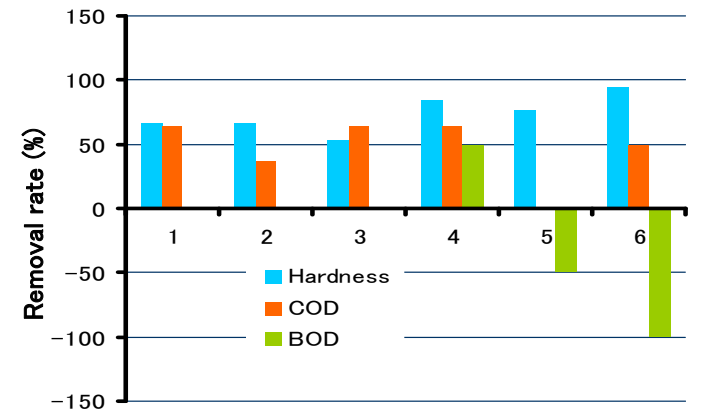

Figure 11. Removal rate of hardness, COD and BOD due to irradiation time (20 min.).

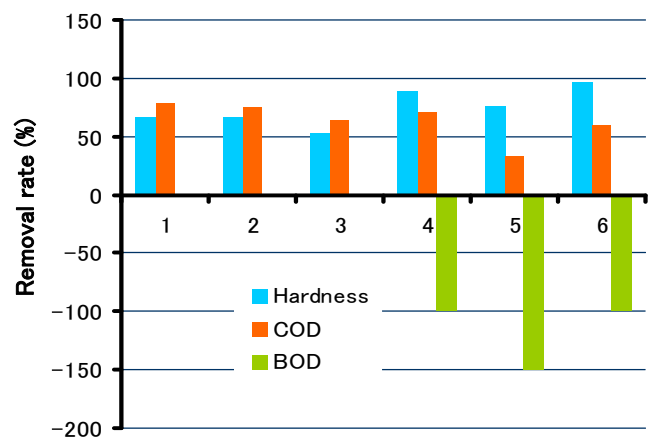

Figure 12. Removal rate of hardness, COD and BOD due to irradiation time (10 $\mathrm{min}$.).

decrease). On the other hand, BOD and COD showed the negative ones (in increase) at approximately half of the samples. It can be seen from the change of the impurities (Tables 2-4) that the concentration of the impurities in drinking water decreases due to irradiation, and thereby the increase of the seeming rate of BOD and COD is considered. In that sense, it also can be thought that the impurities were removed completely.

\section{Conclusions}

In this study, an examination for the improvement of 
water treatment process using ultrasonic waves was carried out. As a result, frequency of ultrasonic waves affecting water quality describing hardness, especially the content of calcium $(\mathrm{Ca})$, sodium $(\mathrm{Na})$, potassium $(\mathrm{K})$ and magnesium $(\mathrm{Mg})$ was confirmed. There will be a possibility to make tasty, healthy and immune water if we could have water containing many of the ingredients such as $\mathrm{Ca}, \mathrm{K}$ and $\mathrm{SiO}_{2}$.

Regarding the removal rate of the hardness, BOD and COD due to irradiation time, the removal rate of the hardness component showed high value of about $42 \%$ - 97\% at each irradiation time. On the other, BOD and COD, the possibility of the complete removal of impurities is supposed at each irradiation time.

The experimental results confirmed that the ultrasonic waves accelerated the reaction better and improved the water treatment process as well as taste of water significantly. The experimental results also revealed that it is very difficult to compare the efficiency of water treatment process with the effect among irradiation times (30 min., $20 \mathrm{~min}$. and $10 \mathrm{~min}$.) quantitatively which warranting further examination on this.

\section{REFERENCES}

[1] D. R. Pathak, A. Hiratsuka and Y. Yamashiki, "Influence of Anthropogenic Activities and Seasonal Variation on Groundwater Quality of Kathmandu Using Multivariate Statistical Analysis," In: Peters et al., Eds., Assessment of Water Quality under Changing Climate Conditions, Proceedings of Symposium H04 held during IUGG2011 in Melbourne, IAHS Publications, Vol. 348, No. 24, 2011, pp. 67-72.
[2] Y. Magara, "Water Quality and Public Health in Japan after the Tsunami," Proceedings of Water Convention 2012, IWA, (2012), Session Theme 4: Water Quality \& Health.

[3] M. A. Sameraiy, "A Novel Water Pretreatment Approach for Turbidity Removal Using Date Seeds and Pollen Sheath," Journal of Water Resource and Protection, Vol. 4, No. 3, 2012, pp. 79-92. doi:10.4236/jwarp.2012.42010

[4] U. I. Gaya and A. H. Abdullah, "Heterogeneous Photocatalytic Degradation of Organic Contaminants over Titanium Dioxide: A Review of Fundamentals, Progress and Problems," Journal of Photochemistry and Photobiology C" Photochemistry Reviews, Vol. 9, No. 1, 2008, pp. 1-12. doi:10.1016/j.jphotochemrev.2007.12.003

[5] M. N. Chong, B. Jin, C. W. K. Chow, et al., "Recent Developments in Photocatalytic Water Treatment Technology: A Review," Water Research, Vol. 44, No. 10, 2010, pp. 2997-3027. doi:10.1016/j.watres.2010.02.039

[6] K. Fujita, "Shirarezaru Mizu no Chonouryoku (Unknown Supernatural Water Power) (in Japanese)," Kodansha, 2007, pp. 12-74.

[7] Y. Saeki, "Orugouru ha Nou ni Kiku (Activation of Brain by Music Box) (in Japanese)," Jitsugyou no Nihonsha, 2007, pp. 92-120.

[8] D. H. Oyib, "Ultrasound Technology in Water Treatment: Suppressing Algal Growth and Biofilm Formation," 2013. http://www.water-world.com/articles/2009/05/ultrasoundtechnology-in-water-treatment-suppressing-algal-growthand-biofilm-formation.html

[9] S. Hashimoto, "Evaluation of Water Quality of Healthy and/or Tasty Drinking Water and Its Application to Japanese Waters (in Japanese)," Journal of SHASE, Vol. 63, No. 6, 1989, pp. 463-468. 